\title{
Establishing a Cost Basis for Converting the High Flux Isotope Reactor from High Enriched to Low Enriched Uranium Fuel
}

January 31, 2010

\author{
Prepared by
}

Tracey Guida

R. T. Primm, III

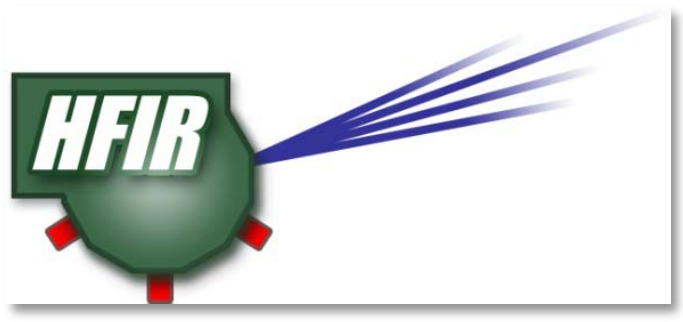




\section{DOCUMENT AVAILABILITY}

Reports produced after January 1, 1996, are generally available free via the U.S. Department of Energy (DOE) Information Bridge.

Web site http://www.osti.gov/bridge

Reports produced before January 1, 1996, may be purchased by members of the public from the following source.

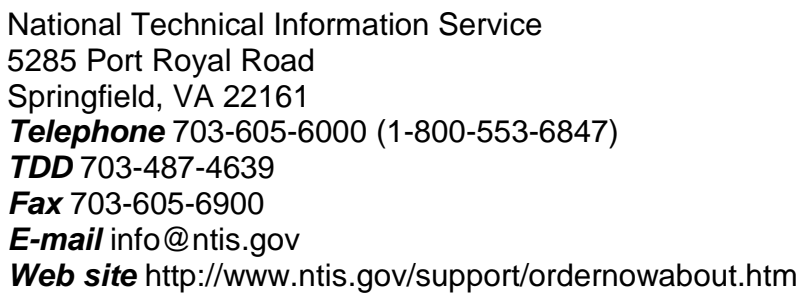

Reports are available to DOE employees, DOE contractors, Energy Technology Data Exchange (ETDE) representatives, and International Nuclear Information System (INIS) representatives from the following source.

Office of Scientific and Technical Information

P.O. Box 62

Oak Ridge, TN 37831

Telephone 865-576-8401

Fax 865-576-5728

E-mail reports@osti.gov

Web site http://www.osti.gov/contact.html

This report was prepared as an account of work sponsored by an agency of the United States Government. Neither the United States Government nor any agency thereof, nor any of their employees, makes any warranty, express or implied, or assumes any legal liability or responsibility for the accuracy, completeness, or usefulness of any information, apparatus, product, or process disclosed, or represents that its use would not infringe privately owned rights. Reference herein to any specific commercial product, process, or service by trade name, trademark, manufacturer, or otherwise, does not necessarily constitute or imply its endorsement, recommendation, or favoring by the United States Government or any agency thereof. The views and opinions of authors expressed herein do not necessarily state or reflect those of the United States Government or any agency thereof. 
ORNL/TM-2009/311

Research Reactors Division

ESTABLISHING A COST BASIS FOR CONVERTING THE HIGH FLUX ISOTOPE REACTOR FROM HIGH ENRICHED TO LOW ENRICHED URANIUM FUEL

Tracey Guida*

R. T. Primm, III

*University of Pittsburgh

Date Published: January 2010

\author{
Prepared by \\ OAK RIDGE NATIONAL LABORATORY \\ Oak Ridge, Tennessee 37831-6283 \\ managed by \\ UT-BATTELLE, LLC \\ for the \\ U.S. DEPARTMENT OF ENERGY \\ under contract DE-AC05-00OR22725
}





\section{CONTENTS}

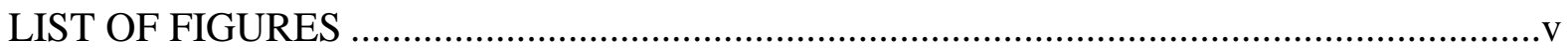

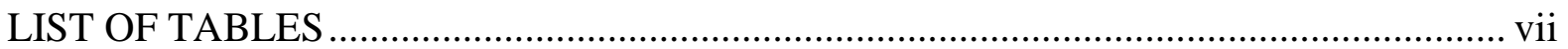

ACKNOWLEDGEMENT …........................................................................................ ix

ACRONYMS AND ABBREVIATIONS ................................................................... xi

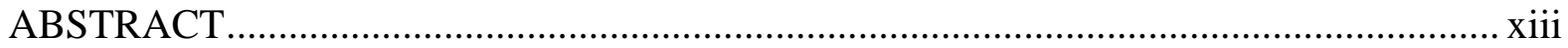

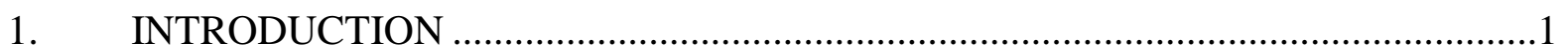

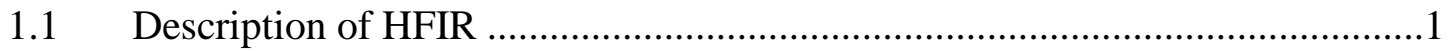

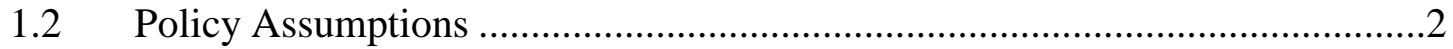

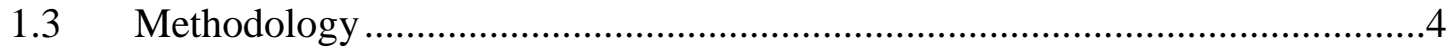

2. COMPONENTS OF THE POST-FABRICATION HFIR FUEL CYCLE ..................7

2.1 Input Required from Organizations Outside ORNL .......................................

2.2 Quality Assurance Monitoring/Approval by HFIR Staff.................................

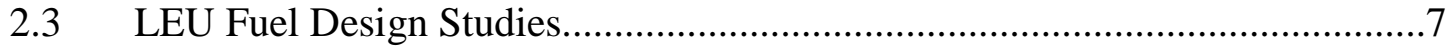

2.4 Fresh Fuel Shipping Container ............................................................

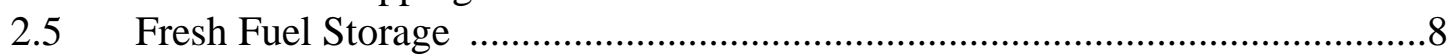

2.6 Operations Inside the HFIR Building ......................................................

2.7 Operations with Spent Fuel Outside the Reactor ..........................................11

3. SUMMARY AND CONCLUSIONS ...............................................................15

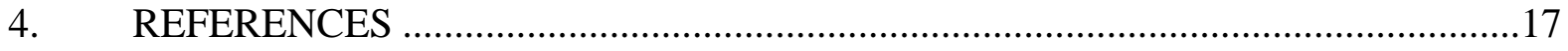

Appendix A. RISKS AND OPPORTUNITIES ........................................................19 



\section{LIST OF FIGURES}

Page

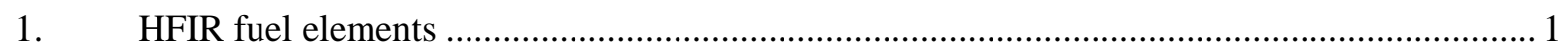

3.1 Conversion project annual expense ................................................................................. 14

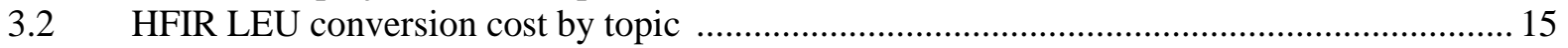





\section{LIST OF TABLES}

Page

Input required for organizations outside ORNL ............................................

$2.2 \quad$ Quality Assurance, Design, and Fresh Fuel Shipping Tasks .............................10

$2.3 \quad$ Operations conducted inside the HFIR building..............................................12

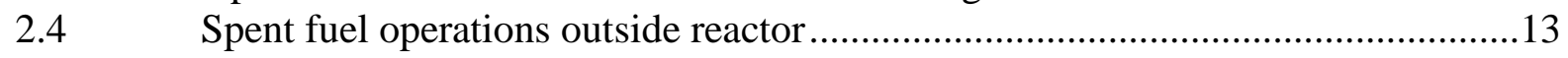

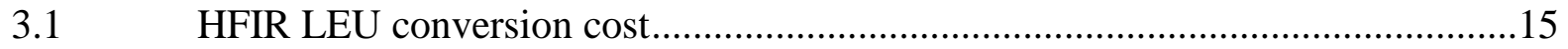





\section{ACKNOWLEDGMENTS}

The authors would like to acknowledge that the support for this project was provided by the Global Threat Reduction Initiative, Reduced Enrichment for Research and Test Reactors Program, National Nuclear Security Administration, U.S. Department of Energy. The first author, Tracey Guida, was a participant in the Pre-Service Teacher Training Fellowship Program at Oak Ridge National Laboratory during the time these studies were conducted. Appendix A was prepared by D. G. Renfro, Research Reactors Division (RRD), Oak Ridge National Laboratory (ORNL). Review of the manuscript by Kevin A. Smith and the careful formatting of the document by Mary Wells, both of RRD, ORNL, are very much appreciated and acknowledged. 


\section{ACRONYMS AND ABBREVIATIONS}

$\begin{array}{ll}\text { ATR } & \text { Advanced Test Reactor } \\ \text { DOE } & \text { U.S. Department of Energy } \\ \text { HEU } & \text { high enriched uranium } \\ \text { HFIR } & \text { High Flux Isotope Reactor } \\ \text { IFE } & \text { inner fuel element } \\ \text { INL } & \text { Idaho National Laboratory } \\ \text { ISM } & \text { Integrated Safety Management } \\ \text { LEU } & \text { low enriched uranium } \\ \text { NNSA/DOE } & \text { National Nuclear Security Administration/Department of Energy } \\ \text { OFE } & \text { outer fuel element } \\ \text { ORNL } & \text { Oak Ridge National Laboratory } \\ \text { RERTR } & \text { Reduced Enrichment for Research and Test Reactors Program } \\ \text { SNF } & \text { Spent Nuclear Fuel } \\ \text { SRS } & \text { Savannah River Site } \\ \text { SST } & \text { safe, secure transport }\end{array}$




\begin{abstract}
Under the auspices of the Global Threat Reduction Initiative - Reduced Enrichment for Research and Test Reactors Program, the National Nuclear Security Administration /Department of Energy (NNSA/DOE) has, as a goal, to convert research reactors worldwide from weapons grade to non-weapons grade uranium. The High Flux Isotope Reactor (HFIR) at Oak Ridge National Laboratory (ORNL) is one of the candidates for conversion of fuel from high enriched uranium (HEU) to low enriched uranium (LEU). A preliminary plan, including tasks, costs, and schedules for conversion of HFIR fuel was developed to provide initial input to the multi-reactor conversion program integrated plan. Using Microsoft Project, a detailed outline of the conversion program was established and consists of LEU fuel design activities, a fresh fuel shipping cask, improvements to the HFIR reactor building, and spent fuel operations. Current-value costs total \$76 million dollars, include over 100 subtasks, and will take over 10 years to complete. The model and schedule follow the path of the fuel from receipt from fuel fabricator to delivery to spent fuel storage and illustrates the duration, start, and completion dates of each subtask to be completed. Assumptions that form the basis of the cost estimate have significant impact on cost and schedule. This preliminary plan is subject to revision based on feedback from the multi-reactor conversion program manager and other emerging developments.
\end{abstract}





\section{INTRODUCTION}

An engineering design study for a fuel that would enable the conversion of the High Flux Isotope Reactor (HFIR) from high enriched uranium (HEU) to low enriched uranium (LEU) is ongoing as part of an effort sponsored by the U.S. Department of Energy's (DOE) National Nuclear Security Administration through the Global Threat Reduction Initiative/ Reduced Enrichment for Research and Test Reactors Program (RERTR). The conversion of the reactor implies the creation of a new fuel cycle both because the form of the LEU fuel is different from the current HEU fuel - a metal alloy rather than a blend of ceramic and metal powders - and because achieving the goal of a proliferation resistant fuel cycle makes obsolete the transportation and storage processes that have been in use for over 40 years. A study was conducted of the impact of fuel conversion on all parts of the fuel cycle that follow fabrication of HFIR fuel elements. The study was performed to provide input to a larger, five-reactor integrated conversion program schedule being developed at the Idaho National Laboratory.

\subsection{DESCRIPTION OF HFIR}

The HFIR is an 85 MW, very high flux, pressurized light-water-cooled and moderated, flux-trap type reactor, which is operated at the Oak Ridge National Laboratory (ORNL). The primary mission of HFIR is to support neutron scattering experiments. Other missions include isotope production, materials irradiation research, and neutron activation analyses. The reactor core consists of a series of concentric annular regions: a central flux trap containing vertical experimental targets surrounded by two fuel elements separated by a thin water region, a region containing two control plates, a beryllium reflector, and a water region to the edge of the pressure vessel, which is located in a pool of water. Details of the reactor configuration and operation can be found elsewhere. ${ }^{1,2}$

The two fuel elements in HFIR are identified as inner fuel element (IFE) and outer fuel element (OFE). They are composed of numerous, involute-shaped fuel plates $1.27 \mathrm{~mm}$-thick, as illustrated in Fig. 1.(a). The plates are separated by a water-filled cooling channel $1.27 \mathrm{~mm}$-thick, and are held together by two cylindrical aluminum side walls. The fuel plates have a sandwich-type design, with a fuel region enclosed in an aluminum-based clad, as illustrated in Fig. 1.(b). The current, HEU, fuel meat inside the fuel region contains a mixture of aluminum powder and uranium oxide $\left(\mathrm{U}_{3} \mathrm{O}_{8}\right)$ with $93.1 \mathrm{wt} \%{ }^{235} \mathrm{U}$ enrichment and is characterized by variable thickness along the width of the fuel plate (radial grading) and a uniform thickness along the length of the fuel plate for a given radius (no axial grading).

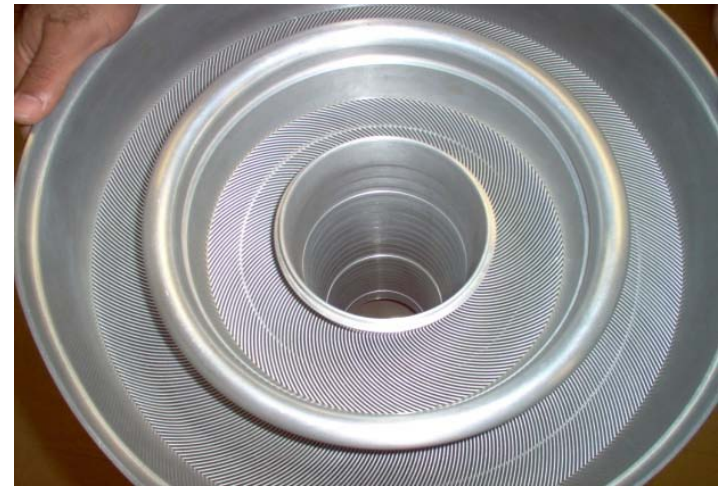

a) inner and outer fuel elements

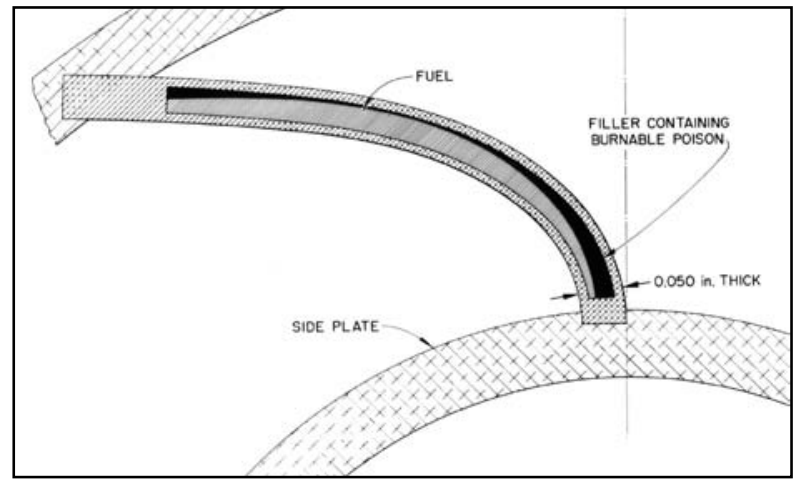

(b) fuel plate profile

Fig. 1. HFIR fuel elements. 
LEU fuel for HFIR will have the same geometry and dimensions as shown in Fig. 1 but the fuel "meat" region, designated as "fuel" in Fig. 1b, will be an alloy of uranium and molybdenum; the uranium having an enrichment of $19.75 \%$. The fuel will be have a graded thickness as is shown in Fig. $1 \mathrm{~b}$ but the profile will be different from the current fuel. The current design for the LEU fuel is for the fuel to have an axial variation in fuel thickness (axial grading) along the lowermost $3 \mathrm{~cm}$ of the fuel. Design studies of the LEU fuel are reported in Refs. 3-5.

\subsection{POLICY ASSUMPTIONS}

Questions of cost and schedule for HFIR fuel conversion were first addressed in Ref. 3. A result of those studies was the observation that obtaining even order-of-magnitude cost estimates required establishing certain assumptions some of which had not yet been considered, much less approved, by program management. Likewise for this study, various "ground rules" were established at the start of the study. These ground rules are elaborated below along with any corollaries that derive from the assumptions.

1) The Department of Energy - Office of Science endorses the conversion of HFIR from HEU to LEU fuel. On September 29, 2009, a letter was sent from Dr. Kelly Beierschmitt, Oak Ridge National Laboratory, to Dr. Parrish Staples, National Nuclear Security Administration, Department of Energy in which Dr. Beierschmitt stated, "it is theoretically feasible to convert the reactor to the use of monolithic U/Mo LEU fuel”. While it is the responsibility of NNSA to develop the LEU fuel and fund this development, HFIR staff, funded by Office of Science to operate the HFIR, will be needed to perform many of the analyses/tasks described subsequently in the schedule. The HFIR facility, itself, will be needed for the conduction of reactor physics tests for LEU fuel. It is assumed that Office of Science will allow these resources to be assigned to NNSA to conduct the tasks identified in the schedule.

2) Organizations outside of ORNL complete identified tasks as scheduled. The LEU conversion program is divided among many organizations including Idaho National Laboratory, Los Alamos National Laboratory, Argonne National Laboratory, the Y-12 National Security Complex, Babcock and Wilcox Nuclear Operations Group, and Oregon State University. It is the responsibility of ORNL to identify input needed from these organizations as part of the integrated conversion program schedule. These items are noted in the schedule presented in this document. It is the responsibility of the conversion program to fund the requested items, ensure the quality of the items, and deliver them to ORNL according to the conversion program integrated schedule.

3) All LEU conversion operations at HFIR will be conducted in compliance with the ORNL Research Reactors Division engineering configuration management process and the elements of DOE-STD-1189 (Ref. 6). DOE-STD-1189 addresses integration of safety into the design process. These processes were considered in the HFIR schedule.

4) With the creation of separate interim and commercial fuel fabrication tasks, if HFIR fuel is fabricated as a part of the interim fuel fabrication task, NNSA will fund the first HFIR reactor core from each task, that is, the first from interim and the first from commercial. Since the beginning of the LEU conversion program, NNSA has agreed to fund the initial LEU core loaded

to HFIR. At the inception of the LEU conversion program, it was not envisioned that there would be a separate, interim fuel fabrication task. Since interim and commercial fuel fabricators may employ different processes, likely will employ different groups of people, and certainly will be at different physical locations, it is the responsibility of NNSA to fund the initial HFIR core from each fabrication task. 
5) HFIR LEU fuel will be stored at the Y-12 site. Since the startup of HFIR, the fresh fuel, being HEU, has been stored at the Y-12 plant. Currently 24 cores - about 3 years of inventory at the current consumption rate - are stored at Y-12. Mr. Morris E. Hassler, Director of Strategic Development / Science, Technology, and Partnerships / Y-12 provided the following information by electronic mail correspondence, "Y-12 will continue to store HFIR fresh fuel in the future. As the fuel is converted from HEU to LEU, Y-12 will then store the HFIR fresh fuel in lower category storage areas instead of high security storage areas as we do now. The Y-12 Master Plan (Y/MOD-0150) documents this continued storage of Category III/IV materials. The LEU materials will be stored in the current warehouse after the HEU material is moved out. Also, I reviewed the latest Y-12 SWEIS (DOE/EIS-0387) and it mentions specifically continuing to support research reactors in supplying fuels including LEU.”

6) After the initiation of fueling of the other U.S.HEU-fueled reactors with LEU, NNSA will compensate HFIR for any increase in HEU fuel fabrication cost that is attributable to a reduction in demand for HEU fuel fabrication services. HFIR fuel operations are not independent of the other four, high performance reactors. The reduction in HEU use as reactors are converted will lead to a greater portion of the fuel fabrication burden (overhead) being assigned to HFIR. Compensation for this increase is consistent with NNSA statements that operations at reactors will not be significantly affected by fuel conversion. HFIR operations must be insured against added fuel costs due to being the last reactor to convert.

7) Savannah River Site will be the disposal point for spent LEU fuel and therefore the end point for any ORNL responsibility related to HFIR fuel.

Through the National Environmental Policy Act, a decision was made in 1995 to consolidate DOE-owned SNF [spent nuclear fuel] at existing DOE sites that have the skills, facilities, and technologies to best handle the fuel. Based on the decisions from the associated environmental impact statement, DOE will temporarily store its SNF at the Hanford Site in Washington, the Idaho National Laboratory (INL) in Idaho, and the Savannah River Site (SRS) in South Carolina until a repository is completed. The Hanford Site will retain most of its current inventory of SNF. The remaining DOE SNF will be consolidated at either the INL or SRS, depending on the type of fuel. ... SRS provides for the safe receipt and interim storage of SNF assemblies including SNF from domestic and foreign test and research reactors. Only L-Basin still contains and receives SNF. The basins have concrete walls 3 feet thick and hold 3.5 million gallons of water with pool depths of 17 to 30 feet to provide cooling and shielding to protect workers from radiation. The SNF stored and received at L-Basin is either planned to be transferred to H-Area facilities for processing and disposition or to INL for consolidation and to prepare and package into a "road ready" condition. (Ref. 7)

HFIR will fabricate whatever tools are necessary to unload LEU fuel at Savannah River site and will be responsible for any required engineering analyses up to the point at which Savannah River Site takes custody of the LEU fuel.

8) Since the overall cost associated with conversion to LEU fuel should not increase the annual operating expenditure for the owner/operator, NNSA will fund any increase in annual operating costs due to LEU for the lifetime of the reactor. Frequently, when changing an industrial process, there is more than one path to achieving the desired outcome. Choices result in a trade-off between capital investment and labor cost; increasing one lowers the other. In these studies, when options were available, the choice was made to maintain (or minimize the increase in) 
operating cost at the expense of potentially higher capital cost (investment). The LEU conversion program will support the choice that minimizes annual operating (labor) cost to HFIR. Staff at ORNL have estimated that the annual production cost of LEU fuel will be at least twice the annual cost of HEU fuel (Ref. 8) even continuing to assume that the cost of the LEU itself is not included (Ref. 3). Therefore, because the current, HEU fuel cost is approximately $15 \%$ of the total operating budget for HFIR, it has been assumed that NNSA will provide a $10 \%$-ofoperating-cost subsidy to HFIR for every year that the HFIR operates once conversion of HFIR to LEU fuel is achieved. The financial implications of this policy assumption are significant - a potential cost of over \$200 million - and, in fact, far exceed the sum of the costs of all other items in the HFIR conversion schedule. Furthermore, the actual cost of the LEU fuel will not be known until a commercial process attains greater definition/development than that described in Ref. 8. It is possible that LEU fuel cost could be the same or less than HEU fuel cost once a fabrication facility is constructed, especially if the RERTR program adheres to the philosophy of minimizing operating cost even at the expense of increased capital cost. As a consequence, this estimated, annual subsidy is not included in the schedule and costs presented subsequently as the authors felt it would obscure/overwhelm other, important concerns. This policy issue, though, should be acknowledged and addressed by the appropriate parties funding HFIR studies and operations.

\subsection{METHODOLOGY}

Determination of the components of the conversion schedule, the duration of the tasks, and the estimated cost were made using the same methodology as described in Ref. 3. The schedule was prepared using the Delphi technique and is based on a "success-driven" assumption, that is, the assumption is made that no unforeseen problems occur during the lifetime of the project.

Managers in the ORNL Research Reactors Division responsible for operations, safety, fabrication, and environmental impact were consulted for cost and scheduling estimates for changes to the HFIR site to accommodate an LEU fuel cycle. The result of these discussions was a preliminary cost estimate of the required capital improvements, safety analysis updates, changes to Technical Safety Requirements, procedural modifications, and required training to support the implementation of core conversion.

The assessment was limited to operations at the HFIR site (7900 area of ORNL) because the RERTR program has funded other organizations to develop fuel production capabilities and fuel plate and fuel element fabrication capabilities. Consequently, these fuel production costs were excluded from this study. The cost of $19.75 \%$ enriched uranium was also not considered. Currently the HFIR annual budget includes payment for the processing of HEU into $\mathrm{U}_{3} \mathrm{O}_{8}$ but not for the HEU itself. Possible sources of LEU include down-blending HEU or the purchase of the material from an enrichment facility. Either would incur costs that are not a part of the HEU fuel cycle. Likewise, an assessment of the acceptability of uraniummolybdenum for long-term storage of spent fuel was not performed because that operation will not be at the ORNL site. (Ref. 3, p. 19)

The schedule includes capital improvements required to HFIR to run the reactor with the LEU fuel at 100 MW to recover the flux lost to the beam tubes due to converting from HEU to LEU.

The HFIR schedule development process began by tracing the path of the fuel elements from the time they left the fuel fabrication facility until they were delivered to the Savannah River Site. Current costs for these operations with HEU fuel are known. Consequently the staff focused on differences between the HEU and LEU fuel cycles and then estimated the time and cost to resolve or accommodate these differences. The completion date for conversion was constrained to be the loading of the first LEU core to HFIR by the end of fiscal year 2016 (September 30, 2016) to meet conversion program integrated schedule expectations. The schedule was developed by working backwards in time from that date. Dates 
of completion for activities by others have been assumed. A secondary consideration was to levelize the annual expenditures as much as possible (similar level of funding year-to-year).

Per request of program management, Microsoft Project software was used to prepare the schedule. Upon completion of the study documented here, the draft Project file was forwarded to program management in September 2009 for integration into a multi-facility schedule. Subsequent to providing the requested schedule to program management, two policy decisions were made that resulted in deletions from the original schedule - deletion of a fresh fuel storage facility at the HFIR site and deletion of a parity HEU fuel experiment. Hence, tables, charts, and graphs contained in this report are a subset of those contained in the version of the Project file that was previously supplied to program management. No additions and no other schedule adjustments were made to the file that had been sent to program management. A revised file will be provided to reflect these deletions. Some comments regarding risks and opportunities associated with the schedule that were requested by program management are provided in Appendix A. Based on feedback from the conversion program manager, this HFIR conversion plan will be updated to reflect integration with the overall conversion program plan. 


\section{COMPONENTS OF THE POST-FABRICATION HFIR FUEL CYCLE}

The HFIR schedule can be subdivided according to fuel operations, i.e. transportation, irradiation, spent fuel storage, spent fuel transportation, etc. Each of these subdivisions is presented separately.

\subsection{INPUT REQUIRED FROM ORGANIZATIONS OUTSIDE ORNL}

The HFIR conversion schedule is a portion of a large effort to prepare an integrated conversion schedule for all U.S. high performance reactors. To enable integration, those areas in which input is needed from organizations outside ORNL before work can begin at HFIR have been collected into a single schedule category. With a few notable exceptions, there are no ORNL costs associated with the provision of these data. Yet the data must be provided on a timely basis if ORNL is to meet the schedule documented here. Table 2.1 contains a list of data/information needs.

Entries 5-16 of Table 2.1 correspond to the policy assumptions enumerated in Section 1.2. These entries are the only ones for which costs accrue at ORNL. The principal cost, $\$ 8.4$ million, corresponds to the estimated increase in HFIR HEU fuel cost during the time period before HFIR conversion and due to conversion of the other high performance reactors. The figure is derived from the fact that approximately $25 \%$ of the annual cost of production of U.S. HEU research reactor fuel is for reactors other than HFIR and the Advanced Test Reactor (ATR). If that production cost is borne by HFIR for six years, an incremental cost of $\$ 8.4$ million is found.

LEU fuel qualification is the responsibility of INL. Hydraulic flow test data will be measured in experiments performed at Oregon State University under the direction of INL. These data will be one of components of the safety basis for LEU fuel in HFIR and are needed before safety-related analyses are initiated.

Similar to fuel qualification, fuel fabrication data are needed in order to define manufacturing tolerances for fuel parameters. Both design basis tolerances (manufacturing specifications) and the accuracy and precision of the devices to be used to confirm design dimensions and fuel characteristics are needed. These data are input to safety-related analyses.

\subsection{QUALITY ASSURANCE MONITORING/APPROVAL BY HFIR STAFF}

Entries 55-64 of Table 2.2 are "placeholders". HFIR quality assurance staff are actively involved in all phases of the current, HEU fuel cycle. Powder production, shipping and transportation, and fuel fabrication operations are all monitored and reviewed by HFIR staff. Safe operation of the reactor - the responsibility of the HFIR staff - requires that fuel be manufactured to exacting standards. This same relationship must be established for a new, LEU fuel cycle. As has been noted earlier in this report, insufficient information on the reference production process exists (Ref. 8). Lack of data inhibits accurate estimation of cost and schedule. Due to the relatively short time to conversion, HFIR staff should be made aware of the fabrication processes as they are being developed. Estimated costs generally reflect 1 to 2 person-months of effort per fiscal year per segment of the fabrication process and allow for the fact that fuel fabrication operations will be geographically distant from Oak Ridge.

\subsection{LEU FUEL DESIGN STUDIES}

Entries 66-86 of Table 2.2 are the continuation of studies initiated in 2005 at ORNL; initial studies documented in Ref. 3-5. The goals of these future studies are to document the current LEU HFIR fuel design, develop engineering drawings, and forward these data to fuel qualification and fuel fabrication tasks. In addition, thermal hydraulics studies will be conducted with the aim of developing and certifying advanced, finite-element-based analysis techniques. Studies to date indicate that by using these modern 
analysis techniques, unnecessary conservatism in the current LEU HFIR fuel design could be eliminated and therefore the fabrication processes made to be simpler and cheaper.

For the current, HEU fuel cycle, the fuel manufacturing specification was developed by ORNL staff and then supplied to the fabricator as a part of the contracting process for procuring reactor fuel. Revisions to the fuel specification are the contractual responsibility of the HFIR staff. Contractually, the fuel specification for LEU fuel will be required to be approved by the staff of the contractor for Oak Ridge National Laboratory. This contractual requirement, coupled with the technical expertise of the HFIR staff (Ref. 8), are the bases for the table entries related to materials and fabrication.

\subsection{FRESH FUEL SHIPPING CONTAINER}

The HFIR LEU core geometry will be unchanged from the current HEU design. Consequently the LEU core will fit into the current shipping container. However, the weight of an LEU core will be approximately $30 \%$ greater than the current HEU core. Furthermore, due to the changes in both the quantity and enrichment of uranium, the container must be relicensed. Relicensing includes, among other things, structural and criticality safety analyses. Currently, HEU fuel elements are transported by safe, secure transport (SST). With the reduction in enrichment, commercial transport may be utilized. There is some possibility that the current fresh fuel shipping containers, even when reanalyzed for LEU fuel, would not be acceptable to licensing authorities. Three federal agencies, Department of Energy, Department of Transportation, and the Nuclear Regulatory Commission, will have to certify the new container for LEU fuel. These analyses and reviews are reflected in entries 88-103 of Table 2.2.

\subsection{FRESH FUEL STORAGE}

HFIR is refueled 7-8 times a year. At each refueling, both inner and outer elements are replaced. Since the HFIR fuel cycle is short ( 25 days) and since the production time for a HFIR fuel element is approximately 2 years, the goal for the inventory of fresh HFIR elements has been set at a level to meet four years of consumption (30-32 cores at the current rate of consumption). At present, the Department of Energy has authorized the storage of 3 fresh cores at the HFIR site. Usually there is only one fresh core on site at HFIR and that occurs on a just-in-time basis. Delivery of the fresh core is usually scheduled just before expected cycle shutdown and one goal of operations at HFIR is to have the fresh fuel located outside the reactor vessel for the minimum amount of time. Consequently the balance of the inventory of HFIR elements (currently 24 cores) is stored at the Y-12 plant.

LEU fuel will be stored at Y-12 in lower category storage areas instead of high security storage areas currently used for HEU. The Y-12 Master Plan (Y/MOD-0150) documents this continued storage of Category III/IV materials. No significant changes in cost are expected with LEU HFIR assemblies. Fresh fuel storage has no impact on the HFIR conversion schedule.

\subsection{OPERATIONS INSIDE THE HFIR BUILDING}

The building containing the High Flux Isotope Reactor is designated as 7900 and includes fresh fuel receipt areas, spent fuel storage arrays, various balance-of-plant systems, and research areas for experimenters. Since LEU elements will be approximately 30\% heavier than the current HEU elements and since various fuel handling tools are certified only for operation with current elements, expert opinion is that new fuel handling tools must be designed, fabricated and certified for use with LEU elements. Structural analyses must be performed for both fresh and spent fuel operations. 
Table 2.1 Input required from organizations outside ORNL

\begin{tabular}{|c|c|c|c|c|c|c|}
\hline D & & Task Name & Cost & Duration & Start & Finish \\
\hline & (9) & & & & & \\
\hline 3 & & Input required from organizations outside UT-Battelle/ORNL & $\$ 8,460,000.00$ & 89.2 mons & Thu 10/1/09 & Tue $8 / 2 / 16$ \\
\hline 4 & & Policy decisions & $\mathbf{s 8 , 4 6 0 , 0 0 0 . 0 0}$ & 89.2 mons & Thu 10/1/09 & Tue 8/2/16 \\
\hline 5 & - & NNSA and DOE-Office of Science & $\mathbf{\$ 8 , 4 5 0 , 0 0 0 . 0 0}$ & 89.2 mons & Thu 10/1/09 & Tue 8/2/16 \\
\hline 6 & I묭 & HFIR staff prepare presentation to Office of Science & $\$ 20,000.00$ & 1 mon & Thu $10 / 1 / 09$ & Wed 10/28/09 \\
\hline 7 & 善) & Office of Science/NNSA workshop to discuss HFIR status within GTRI & $\mathbf{\$ 5 , 0 0 0 . 0 0}$ & 0.5 mons & Mon 11/2/09 & Fri 11/13/09 \\
\hline 8 & (-) & If within GTRI scope, specification of degree of compliance with DOE-STD-1189 & $\$ 5,000.00$ & 0.5 mons & Mon 11/16/09 & Fri 11/27/09 \\
\hline 9 & (2) & Memorandum of Understanding (MOU) issued between Office of Science and NNSA regarding HFIR status & $\mathbf{s 5 , 0 0 0 . 0 0}$ & 1 mon & Mon $11 / 30 / 09$ & Fri 12/25/09 \\
\hline 10 & 正) & Memorandum of Understanding that NNSA covers costs through first HFIR core from FFC and first core from interi & $55,000.00$ & 0.5 mons & Mon 12/28/09 & Fri $1 / 8 / 10$ \\
\hline 11 & (2) & Memorandum of Understanding that NNSA provides for HFIR fresh fuel storage and location & $\$ 5,000.00$ & 0.5 mons & Mon $1 / 11 / 10$ & Fri $1 / 22 / 10$ \\
\hline 12 & (1) & MOU between SC and NNSA that NNSA fund $10 \%$ of HFIR annual budget for remaining HFIR life & $\$ 5,000.00$ & 0.5 mons & Mon $1 / 25 / 10$ & Fri 2/5/10 \\
\hline 13 & 正(-) & Compensation to HFIR for increased HEU production cost due to conversion of other research reactors & $\$ 8,400,000.00$ & 24 mons & Wed 10/1/14 & Tue $8 / 2 / 16$ \\
\hline 14 & & NNSA, DOE-Office of Science, and Savannah River Site (SRS) & $\mathbf{\$ 1 0 , 0 0 0 . 0 0}$ & 1 mon & Mon 2/1/10 & Fri 2/26/10 \\
\hline 15 & 回) & Inform SRS that (Zr-encased, LEUMMo fuel) clad with Al will be delivered for disposition per DOE EIS & $\mathbf{5 5 , 0 0 0 . 0 0}$ & 0.5 mons & Mon 2/1/10 & Fri $2 / 12 / 10$ \\
\hline 16 & & Memorandum of Understanding between SRS and Office of Science on acceptability of LEU fuel & $\$ 5,000.00$ & 0.5 mons & Mon 2/15/10 & Fri $2 / 26 / 10$ \\
\hline 17 & & Fuel Qualification Data/Analyses/Reports & so.00 & 38.1 mons & Thu 10/1/09 & Fri 8/31/12 \\
\hline 18 & & INL (ATR irradiations) & so.oo & 38.1 mons & Thu 10/1/09 & Fri 8/31/12 \\
\hline 19 & 피) & Distribute program plan for remainder of UMMo irradiation experiments & so.00 & 0.2 mons & Thu 10/1/09 & Tue $10 / 6 / 09$ \\
\hline 20 & 益 & Summary/topical report of U/Mo fuel irradations performed by RERTR & so.00 & $0.2 \mathrm{mons}$ & Mon $3 / 1 / 10$ & Thu $3 / 4 / 10$ \\
\hline 21 & 毌 & Incorporation of RERTR U/MO data wath other U/MO data to complete U/MO Handbook & so.00 & 0.2 mons & Thu $4 / 1 / 10$ & Tue 4/6/10 \\
\hline 22 & & Single driver element in ATR & so.00 & 25.05 mons & Thu 10/1/09 & Thu 9/1/11 \\
\hline 23 & 回 & ORNL attendance at discussions/meetings on approval process for loading LEU fuel to ATR & so.00 & 12 mons & Thu $10 / 1 / 09$ & Wed 9/1/10 \\
\hline 24 & 目 & Summary/topical report of LEU assembly irradiation in ATR & so.00 & 12 mons & Fri 10/1/10 & Thu 9/1/11 \\
\hline 25 & & Multi-element test in one lobe of ATR & so.00 & 12 mons & Mon 10/3/11 & Fri 8/31/12 \\
\hline 26 & 回 & ORNL attendance at discussions/meetings on approval process for loading LEU fuel to ATR & so.00 & 12 mons & Mon 10/3/11 & Fri $8 / 31 / 12$ \\
\hline 27 & 目 & Summary/topical report of LEU assembly irradiation in ATR & so.00 & 12 mons & Mon 10/3/11 & Fri $8 / 31 / 12$ \\
\hline 28 & - & Oregon State University (Flow Test Loop) & so.oo & 16.35 mons & Thu 10/1/09 & Fri 12/31/10 \\
\hline 29 & 正 & OSU to form advisory committee that includes HFIR representative & so.00 & $0.2 \mathrm{mons}$ & Thu $10 / 1 / 09$ & Tue $10 / 6 / 09$ \\
\hline 30 & 毌 & OSU to consider two separate test loops: one for MITMMURRNIST and second for ATRHFIR & so.00 & $0.2 \mathrm{mons}$ & Tue $12 / 1 / 09$ & Fri 12/4/09 \\
\hline 31 & 亚 & OSU/HFIR to develop two surrogate HFIR assembles: inner element and outer element & so.00 & 12 mons & Mon 2/1/10 & Fri 12/31/10 \\
\hline 32 & 益 & OSUMFIR to mutually decide on scope of test matrix & so.00 & $0.2 \mathrm{mons}$ & Thu $4 / 1 / 10$ & Tue 4/6/10 \\
\hline 33 & 国 & Receive data from structural analysis tests & so.00 & $0.2 \mathrm{mons}$ & Fri $10 / 1 / 10$ & Wed 10/6/10 \\
\hline 34 & 耑 & HFIRJOSU determine if heated flow test data are needed/if so modify facilty/send data to MFIR & so.00 & 0.2 mons & Fri $10 / 1 / 10$ & Wed 10/6/10 \\
\hline 35 & & Fuel Fabrication Data/Analyses/Reports & so.oo & $6.7 \mathrm{mons}$ & Thu 10/1/09 & Tue 4/6/10 \\
\hline 36 & & Y-12 (HEU downblend and alloying with Mo) & so.00 & 0.2 mons & Thu 10/1/09 & Tue 10/6/09 \\
\hline 37 & 四 & dentification of contact for quality assurance information/requirements exchange & so.00 & 0.2 mons & Thu $10 / 1 / 09$ & Tue 10/6/09 \\
\hline 38 & 国(-) & Provide specifications for HEU down-blending and alloying fabrication steps & so.00 & 0.2 mons & Thu $10 / 1 / 09$ & Tue $10 / 6 / 09$ \\
\hline 39 & 眀 & Supply samples for fuel qualification tests & so.00 & 0.2 mons & Thu $10 / 1 / 09$ & Tue 10/6/09 \\
\hline 40 & 益它 & Supply estimate of expected cost per plate of operations & so.00 & $0.2 \mathrm{mons}$ & Thu 10/1/09 & Tue 10/6/09 \\
\hline 41 & & LANL (Interim fuel fabrication) & so.00 & 4.6 mons & Thu 10/1/09 & Fri $2 / 5 / 10$ \\
\hline 42 & 四 & Identification of contact for quality assurance information/requirements exchange & so.00 & $0.2 \mathrm{mons}$ & Thu $10 / 1 / 09$ & Tue 10/6/09 \\
\hline 43 & 国) & Provide specifications, including precision and accuracy of measurements & so.00 & 0.2 mons & Tue $2 / 2 / 10$ & Fri $2 / 5 / 10$ \\
\hline 44 & 亚 & Supply samples for fuel qualification tests & so.00 & 0.2 mons & Tue $2 / 2 / 10$ & Fri 2/5/10 \\
\hline 45 & 䀝 & Supply estimate of expected cost per plate of operations & so.00 & $0.2 \mathrm{mons}$ & Tue $2 / 2 / 10$ & Fri $2 / 5 / 10$ \\
\hline 46 & & Commercial fuel fabricator (currently B\&W Lynchburg) & so.00 & 6.7 mons & Thu 10/1/09 & Tue 4/6/10 \\
\hline 47 & & Address issues resulting from Green Field Fabrication Facility proposal & so.oo & 0.2 mons & Thu 10/1/09 & Tue 10/6/09 \\
\hline 48 & 进 & Maintaining fuel supply while transitioning from HEU to LEU & so.00 & 0.2 mons & Thu $10 / 1 / 09$ & Tue $10 / 6 / 09$ \\
\hline 49 & 프 & Documentation of contractual arrangement for linking plate production activity to full element assembly & so.00 & $0.2 \mathrm{mons}$ & Thu $10 / 1 / 09$ & Tue $10 / 6 / 09$ \\
\hline 50 & 益 & Identification of contact for quality assurance information/requirements exchange & so.00 & $0.2 \mathrm{mons}$ & Thu $10 / 1 / 09$ & Tue 10/6/09 \\
\hline s1 & 鄙( & Provide specifications, including precision and accuracy of measurements & so.00 & 0.2 mons & Thu $4 / 1 / 10$ & Tue $4 / 6 / 10$ \\
\hline 52 & 益 & Supply samples for fuel qualification tests & so.00 & $0.2 \mathrm{mons}$ & Thu 4/1/10 & Tue 4/6/10 \\
\hline 53 & 国) & Supply estimate of expected cost per assembly of operations & so.00 & 0.2 mons & Thu $4 / 1 / 10$ & Tue 4/6/10 \\
\hline
\end{tabular}


Table 2.2 Quality Assurance, Design, and Fresh Fuel Shipping Tasks

\begin{tabular}{|c|c|c|c|c|c|c|}
\hline D & (-) & Task Name & Cost & Duration & Start & Finish \\
\hline \multicolumn{7}{|l|}{54} \\
\hline 55 & 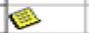 & Quality assurance approval/audit by HFIR staff for operations outside HFIR site & $\$ 600,000.00$ & 100.2 mons & Thu 10/1/09 & Tue 6/6/17 \\
\hline 56 & & Interim fuel fabrication & $\mathbf{\$ 2 5 0 , 0 0 0 . 0 0}$ & 24 mons & Thu 10/1/09 & Wed 8/3/11 \\
\hline 57 & 四 & Operations at $Y-12$ & $\$ 75,000.00$ & 24 mons & Thu 10/1/09 & Wed 8/3/11 \\
\hline 58 & 曲 & Operations at Los Alamos & $\$ 150,000.00$ & 24 mons & Thu 10/1/09 & Wed 8/3/11 \\
\hline 59 & 目 & Operations at Lynchburg & $\$ 25,000.00$ & 24 mons & Thu $10 / 1 / 09$ & Wed $8 / 3 / 11$ \\
\hline 60 & & Fuel Fabrication Capability (site not yet determined) & $\$ 350,000.00$ & 86.1 mons & Mon 11/1/10 & Tue 6/6/17 \\
\hline 61 & 回 & Quality assurance for CD1 stage & $\$ 75,000.00$ & 12 mons & Mon $11 / 1 / 10$ & Fri $9 / 30 / 11$ \\
\hline 62 & 正 & Quality assurance for CD2 stage & $\$ 75,000.00$ & 24 mons & Wed 11/30/11 & Tue 10/1/13 \\
\hline 63 & 益 & Quality assurance for $\mathrm{CD} 3$ stage & $\mathbf{S 1 5 0 , 0 0 0 . 0 0}$ & 36 mons & Wed $10 / 2 / 13$ & Tue $7 / 5 / 16$ \\
\hline 64 & 毌 & Approval of quality assurance plan for $\mathrm{CD} 4$ stage & $\$ 50.000 .00$ & 12 mons & Wed $7 / 6 / 16$ & Tue 6/6/17 \\
\hline \multicolumn{7}{|c|}{65} \\
\hline 66 & & LEU fuel design studies & $\$ 5,515,000.00$ & 48.35 mons & Thu 10/1/09 & Fri 6/14/13 \\
\hline 67 & 표일 & HFIRNNSSA program coordination & $\mathbf{S 1 , 2 0 0 , 0 0 0 . 0 0}$ & 36 mons & Mon $3 / 1 / 10$ & Fri 11/30/12 \\
\hline 68 & 2 & Analyses & $\$ 2,150,000.00$ & 48.35 mons & Thu 10/1/09 & Fri 6/14/13 \\
\hline 69 & & Studies for removing axial grading & $\mathbf{S 1 , 3 0 0 , 0 0 0 . 0 0}$ & 24 mons & Thu 10/1/09 & Wed 8/3/11 \\
\hline 70 & 표 & Implementation of new thermal hydraulic analysis capability & $\$ 800.000 .00$ & 24 mons & Thu $10 / 1 / 09$ & Wed 8/3/11 \\
\hline 71 & 표 & Neutronics studies to reduce/elminate axial fuel grading & $\$ 500,000.00$ & 24 mons & Thu 10/1/09 & Wed $8 / 3 / 11$ \\
\hline 72 & & Flow test measurements at osu & $\mathbf{\$ 8 5 0 , 0 0 0 . 0 0}$ & 48.35 mons & Thu 10/1/09 & Fri 6/14/13 \\
\hline 73 & 프닌 & Advise/review structural analysis tests & $\mathbf{S 1 5 0 , 0 0 0 . 0 0}$ & 36 mons & Thu $10 / 1 / 09$ & Wed $7 / 4 / 12$ \\
\hline 74 & 표인 & Design HFIR segments for OSU test loop & $\$ 200,000.00$ & 9 mons & Mon $1 / 4 / 10$ & Fri $9 / 10 / 10$ \\
\hline 75 & 8 & Analyze data from structural analysis tests & $\$ 500,000.00$ & 36 mons & Mon $9 / 13 / 10$ & Fri $6 / 14 / 13$ \\
\hline 76 & (2) & Development of fuel specifications & $\$ 2,165,000.00$ & 36 mons & Thu 10/1/09 & Wed 7/4/12 \\
\hline 77 & 표 & HFIR staff fuel process review/comment & $\$ 250,000.00$ & 36 mons & Thu 10/1/09 & Wed $7 / 4 / 12$ \\
\hline 78 & 司家 & Materials Science and Technology materials review/comment & $\$ 375,000.00$ & 36 mons & Thu $10 / 1 / 09$ & Wed 7/4/12 \\
\hline 79 & & Interim fuel fabrication & $\mathbf{s 1 , 0 8 0 , 0 0 0 . 0 0}$ & 19.7 mons & Thu 10/1/09 & Tue 4/5/11 \\
\hline 80 & 四 & Develop test plan for measurements to support creation of a fuel specification for interim fuel & $\mathbf{5 3 0 , 0 0 0 . 0 0}$ & 3 mons & Thu 10/1/09 & Wed 12/23/09 \\
\hline 81 & 曲 & Conduct measurements to support fuel specification & $\$ 1,000,000.00$ & 10 mons & Wed $4 / 7 / 10$ & Tue $1 / 11 / 11$ \\
\hline 82 & & Develop/approve fuel specification/drawings for HFIR LEU fuel plates & $\mathbf{\$ 5 0 . 0 0 0 . 0 0}$ & 3 mons & Wed $1 / 12 / 11$ & Tue 4/5/11 \\
\hline 83 & & Commercial fuel fabrication & $\$ 460,000.00$ & 16 mons & Wed 4/6/11 & Tue 6/26/12 \\
\hline 84 & & Develop second test plan for measurements to support creation of a fuel specification for commercial vendor & $\$ 30,000.00$ & 3 mons & Wed 4/6/11 & Tue $6 / 28 / 11$ \\
\hline 85 & 표 & Conduct second set of measurements to support fuel specification & $\$ 400,000.00$ & 10 mons & Wed 6/29/11 & Tue 4/3/12 \\
\hline 86 & (1) & Develop/approve fuel specification/drawings for HFIR LEU fuel plates & $\$ 30,000.00$ & 3 mons & Wed 4/4/12 & Tue $6 / 26 / 12$ \\
\hline \multicolumn{7}{|l|}{87} \\
\hline 88 & 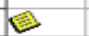 & Fresh Fuel Shipping Cask (from fuel fabricator to HFIR) & $\mathbf{\$ 1 0 , 0 0 0 , 0 0 0 . 0 0}$ & 86 mons & Fri 10/1/10 & Thu 5/4/17 \\
\hline 89 & 血 & Specify fresh fuel characteristics, number of casks, regulations to be followed, approval agencies and approval paths with & $\$ 120,000.00$ & 4 mons & Fri 10/1/10 & Thu 1/20/11 \\
\hline 90 & & Issue Request for Proposals & $\$ 90,000.00$ & 3 mons & Fri $1 / 21 / 11$ & Thu 4/14/11 \\
\hline 91 & & Review Proposals and Down-Select & $\mathbf{5 9 0 , 0 0 0 . 0 0}$ & 3 mons & Fri 4/15/11 & Thu $7 \pi / 11$ \\
\hline 92 & & Selected Vendors Prepare Final Proposals & $\$ 90,000.00$ & 3 mons & Fri 7/8/11 & Thu 9/29/11 \\
\hline 93 & & Vendor Selection & $\$ 30.000 .00$ & 1 mon & Fri 9/30/11 & Thu 10/27/11 \\
\hline 94 & & Develop Detailed Design of Cask & $\mathbf{S 1 8 0 , 0 0 0 . 0 0}$ & 6 mons & Fri 10/28/11 & Thu $4 / 12 / 12$ \\
\hline 95 & & Drop Testing of Prototype Cask & $\$ 360,000.00$ & 12 mons & Fri 4/13/12 & Thu 3/14/13 \\
\hline 96 & & Develop Safety Analysis Report for Cask & $\$ 90,000.00$ & 3 mons & Fri 3/15/13 & Thu 6/6/13 \\
\hline 97 & & Design Review by HFIR Operator & $\$ 90,000.00$ & 3 mons & Fri $6 / 7 / 13$ & Thu $8 / 29 / 13$ \\
\hline 98 & & Design Review by Approval Agencies & $\$ 360,000.00$ & 12 mons & Fri $8 / 30 / 13$ & Thu $7 / 31 / 14$ \\
\hline 99 & & Construct First Cask & $\$ 5,314,000.00$ & 12 mons & Fri 8/1/14 & Thu $7 / 2 / 15$ \\
\hline 100 & & Testing and Certification of Cask & $\$ 180,000.00$ & 6 mons & Fri 7/3/15 & Thu 12/17/15 \\
\hline 101 & & Construct Additional Casks & $\$ 2,820,000.00$ & 12 mons & Fri 12/18/15 & Thu 11/17/16 \\
\hline 102 & & Testing and Certification of Additional Casks & $\mathbf{S 1 8 0 , 0 0 0 . 0 0}$ & 6 mons & Fri 11/18/16 & Thu 5/4/17 \\
\hline 103 & 표 & Shipment of first core to HFIR & $56,000.00$ & 0.2 mons & Mon $12 / 1 / 14$ & Thu 12/4/14 \\
\hline 104 & & & & & & \\
\hline
\end{tabular}


Implementation of the LEU fuel cycle for this study was envisioned to be in two phases. The first phase would be to demonstrate acceptable reactor performance at an operating power level of $100 \mathrm{MW}$. The second phase would be the conversion to LEU fuel. The schedule shown in Table 2.3 includes these two phases.

End-of-cycle exposure for LEU elements will be greater than that for the current fuel elements. A variety of nuclear engineering analyses including radiation source term estimation, dose rate calculations, heat source estimation, and criticality safety calculations will have to be performed for the LEU fuel. All spent fuel operations - unloading of the reactor core, storage of spent fuel, transfer and loading of spent fuel to a shipping cask - will be re-evaluated using data from irradiations in ATR. The results of these studies will then be used to update the HFIR Safety Analysis Report.

\subsection{OPERATIONS WITH SPENT FUEL OUTSIDE THE REACTOR}

Table 2.4 shows LEU fuel operations outside the reactor. Given that the LEU fuel elements have the same dimensions as the current HEU elements, there is a high probability that the current shipping cask (GE2000) can be used for spent LEU fuel. Nevertheless the cask must be licensed for a new fuel type (LEU) and for a greater discharge exposure than that for which it is currently licensed (2300 MWD).

The end point for that portion of the HFIR fuel cycle for which ORNL is responsible is the delivery of the spent fuel to Savannah River Site. Analysis and documentation costs related to the delivery and unloading of the fuel at SRS are assumed to be the responsibility of ORNL. 
Table 2.3. Operations conducted inside the HFIR building

\begin{tabular}{|c|c|c|c|c|c|c|}
\hline D & (9) & Task Name & Cost & Duration & Start & Finish \\
\hline 105 & B) & HFIR Reactor Building (7900) & $\$ 45,400,000.00$ & $135.8 \mathrm{mons}$ & Fri 10/1/10 & Fri 2/26/21 \\
\hline 106 & & Fresh Fuel Operations outside of core & $\$ 3,050,000.00$ & 27 mons & Mon 10/1/12 & Fri 10/24/14 \\
\hline 107 & 표 & 3 New Tools for handling operations inside reactor building + Spares & $51,000,000.00$ & 12 mons & Mon 10/1/12 & Fri $8 / 30 / 13$ \\
\hline 108 & 国 & Analysis of Other Tools & $\$ 500,000.00$ & 12 mons & Mon 10/1/12 & Fri 8/30/13 \\
\hline 109 & 프 & Criticality Assessments & $\$ 500,000.00$ & 15 mons & Mon 10/1/12 & Fri $11 / 22 / 13$ \\
\hline 110 & 善 & Drop Calculations & $\$ 1,000,000.00$ & 12 mons & Mon 10/1/12 & Fri $8 / 30 / 13$ \\
\hline 111 & 夏 & Second On-Site Transport Container from storage to reactor building (not required; will be removed at next schedule re & $\mathbf{5 5 0 , 0 0 0 . 0 0}$ & 12 mons & Mon 11/25/13 & Fri $10 / 24 / 14$ \\
\hline 112 & & Reactor core-related operations & $\mathbf{\$ 3 6 , 8 5 0 , 0 0 0 . 0 0}$ & 135.8 mons & Fri 10/1/10 & Fri $2 / 26 / 21$ \\
\hline 113 & & Implementation step 1: Operation of Reactor at $100 \mathrm{MW}$ & $\mathbf{5 1 3 , 0 4 0 , 0 0 0 . 0 0}$ & 36 mons & Fri 10/1/10 & Thu 7/4/13 \\
\hline 114 & (1) & Address Nuclear, Mechanical, Thermal Characteristics for LEU Fuel at $100 \mathrm{MW}$ & $\mathbf{S 1 0 , 7 7 5 , 0 0 0 . 0 0}$ & 36 mons & Fri 10/1/10 & Thu 7/4/13 \\
\hline 115 & & Reactor Structural Analyses & $\mathbf{5 5 , 0 7 5 , 0 0 0 . 0 0}$ & 36 mons & Fri 10/1/10 & Thu $7 / 4 / 13$ \\
\hline 116 & 四 & Seismic Analysis of Reactor Core Components and Vessel Support & $\$ 2,500,000.00$ & 36 mons & Fri 10/1/10 & Thu 7/4/13 \\
\hline 117 & 표 & StructuravSeismic Analysis of core stack & $\$ 2,500,000.00$ & 36 mons & Fri 10/1/10 & Thu $7 / 4 / 13$ \\
\hline 118 & 亚 & Revise Nuclear Craticality Safety Approval for LEU Fuel & $575,000.00$ & 6 mons & Fri 10/1/10 & Thu $3 / 17 / 11$ \\
\hline 119 & & Accident Analysis & $\$ 5,700,000.00$ & 36 mons & Fri $10 / 1 / 10$ & Thu $7 / 4 / 13$ \\
\hline 120 & 표 & Upgrade Analysis Methodology & $\$ 1,200,000.00$ & 24 mons & Fri 10/1/10 & Thu $8 / 2 / 12$ \\
\hline 121 & 善 & Accident Consequence Analyses & $\$ 4,500,000.00$ & 36 mons & Fri 10/1/10 & Thu $7 / 4 / 13$ \\
\hline 122 & 西 & Analyses for balance of plant operation at $100 \mathrm{MW}$ & \$2,000,000.00 & 6 mons & Fri 10/1/10 & Thu $3 / 17 / 11$ \\
\hline 123 & 亚 & Modify instrumentation & $\$ 250,000.00$ & 6 mons & Mon 10/3/11 & Fri $3 / 16 / 12$ \\
\hline 124 & 표 & Obtain regulatory approval & $\$ 15,000.00$ & 3 mons & Mon 3/19/12 & Fri $6 / 2 / 12$ \\
\hline 125 & & Run cycle at $100 \mathrm{MW}$ & so.00 & $1 \mathrm{mon}$ & Mon 6/11/12 & Fri $7 / 6 / 12$ \\
\hline 126 & & Implementation step 2: Operation of Reactor with LEU fuel at $100 \mathrm{MW}$ & $\$ 23,810,000.00$ & 119.5 mons & Mon 1/2/12 & Fri $2 / 26 / 21$ \\
\hline 127 & 표 & Establish new reactor chemistry program for monitoring reactor coolant & $\$ 300,000.00$ & 4 mons & Mon $1 / 2 / 12$ & Fri $4 / 20 / 12$ \\
\hline 128 & & Obtain regulatory approval for loading fuel & $\$ 10,000.00$ & 3 mons & Mon $4 / 23 / 12$ & Fri $7 / 13 / 12$ \\
\hline 129 & & Core Performance Tests & $\$ 19,500,000.00$ & 49.1 mons & Tue $8 / 28 / 12$ & Wed 6/1/16 \\
\hline 130 & $\square$ & Reactor Control and Safety System Adjustment for New Fuel & $\$ 1,500,000.00$ & 12 mons & Fri $1 / 31 / 14$ & Thu $1 / 1 / 15$ \\
\hline 131 & 国 & Startup Physics Tests (and cycle costs) & $\$ 15,000,000.00$ & 6 mons & Thu $12 / 17 / 15$ & Wed $6 / 1 / 16$ \\
\hline 132 & 而 & Analyses for Physics/Thermal Hydraulic Tests & $\$ 3,000,000.00$ & 36 mons & Tue $8 / 28 / 12$ & Mon $6 / 1 / 15$ \\
\hline 133 & & Start first LEU fuel cycle with fuel from interim fabrication & so.00 & 1 mon & Thu $6 / 2 / 16$ & Wed $6 / 29 / 16$ \\
\hline 134 & 표 & Receive first LEU fuel from FFC & so.00 & 1 mon & Mon $1 / 2 / 17$ & Fri $1 / 27 / 17$ \\
\hline 135 & & PIE of LEU fuel & $\$ 4,000,000.00$ & 24 mons & Mon 4/29/19 & Fri $2 / 26 / 21$ \\
\hline 136 & 표 & Clad exterior, corrosion, erosion & $\$ 1,000,000.00$ & 12 mons & Mon 4/29/19 & Fri $3 / 27 / 20$ \\
\hline 137 & 亚 & Evaluation of fuevdiffusion barrier/clad interfaces & $\$ 1,000,000,00$ & 8 mons & Mon $4 / 29 / 19$ & Fri $12 / 6 / 19$ \\
\hline 138 & 표 & Power profile via uranium depletion & $\$ 1,000,000.00$ & 12 mons & Mon $4 / 29 / 19$ & Fri $3 / 27 / 20$ \\
\hline 139 & 囬 & Disposal cost for assayed element & S1,000,000.00 & 12 mons & Mon $3 / 30 / 20$ & Fri $2 / 26 / 21$ \\
\hline 140 & 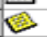 & Spent fuel operations outside of core & $\$ 5,500,000.00$ & 24 mons & Fri 10/1/10 & Thu 8/2/12 \\
\hline 141 & & Analyses Related to Discharged Fuel & $\$ 1,000,000.00$ & 12 mons & Fri 10/1/10 & Thu 9/1/11 \\
\hline 142 & 四 & End of Cycle Source Terms, Decay Heat, Fission Products & $\$ 500,000.00$ & 9 mons & Fri $10 / 1 / 10$ & Thu 6/9/11 \\
\hline 143 & 표 & Consequence Analysis (Fission Product Transport) & $\$ 500,000.00$ & 12 mons & Fri 10/1/10 & Thu $9 / 1 / 11$ \\
\hline 144 & & Removal of Spent Fuel & $\$ 400,000.00$ & 12 mons & Fri 10/1/10 & Thu 9/1/11 \\
\hline 145 & 표 & Drop Analys is & $\$ 300.000 .00$ & 12 mons & Fri 10/1/10 & Thu $9 / 1 / 11$ \\
\hline 146 & 鄙 & Fuel Up-righting Methodology & $\$ 50,000.00$ & 3 mons & Fri 10/1/10 & Thu $12 / 23 / 10$ \\
\hline 147 & 善 & Hoist issues & $\$ 50,000.00$ & 1 mon & Fri 10/1/10 & Thu $10 / 28 / 10$ \\
\hline 148 & & Spent Fuel Storage & $\$ 2,300,000.00$ & 12 mons & Fri 10/1/10 & Thu 9/1/11 \\
\hline 149 & 回 & Structural Analysis: Shielding. Thermal, Criticalty & $\$ 2,000,000.00$ & 12 mons & Fri 10/1/10 & Thu 9/1/11 \\
\hline 150 & 亚 & Requalification of Gamma Irradiation Facinty & $\$ 150,000.00$ & 6 mons & Fri $10 / 1 / 10$ & Thu $3 / 17 / 11$ \\
\hline 151 & 善 & Environmental Assessment & $\mathbf{S 1 5 0 , 0 0 0 . 0 0}$ & 6 mons & Fri 10/1/10 & Thu $3 / 17 / 11$ \\
\hline 152 & & Documentation & $\$ 1,500,000.00$ & 24 mons & Fri 10/1/10 & Thu 8/2/12 \\
\hline 153 & 표 & Upgraded approval & S1,500,000.00 & 24 mons & Fri $10 / 1 / 10$ & Thu $8 / 2 / 12$ \\
\hline 154 & 善 & Sabotage Assessment & $\$ 300,000.00$ & 6 mons & Fri 10/1/10 & Thu $3 / 17 / 11$ \\
\hline 155 & & & & & & \\
\hline
\end{tabular}


Table 2.4. Spent fuel operations outside reactor

\begin{tabular}{|c|c|c|c|c|c|c|}
\hline $\mathbf{D}$ & & Task Name & Cost & Duration & Start & Finish \\
\hline 156 & 당 & Spent Fuel Shipping Cask & $\$ 1,090,000.00$ & 124 mons & Fri 10/1/10 & Thu 4/2/20 \\
\hline 157 & 표 & Irradiated Fuel Tools: Analysis and Design & $\$ 300,000,00$ & 6 mons & Fri 10/1/10 & Thu $3 / 17 / 11$ \\
\hline 158 & 园 & Relicensing of Cask and Analysis: Thermal, Structural, Shielding, Criticalty (analyze and modify as needed) & $\$ 750,000.00$ & 12 mons & Fri $10 / 1 / 10$ & Thu $9 / 1 / 11$ \\
\hline 159 & 四 & Ship first LEU core to Savannah River Site & $\$ 40,000.00$ & 0.2 mons & Mon $3 / 30 / 20$ & Thu $4 / 2 / 20$ \\
\hline \multicolumn{7}{|l|}{160} \\
\hline 161 & 상 & HFIR to Savannah River Site - Receipt of spent fuel & $\$ 5,000,000.00$ & 137.2 mons & Mon 10/26/09 & Thu 4/30/20 \\
\hline 162 & 四 & Record of Decision for DOE/EIS-0203 & $\mathbf{\$ 0 . 0 0}$ & 1 mon & Mon 10/26/09 & Fri 11/20/09 \\
\hline 163 & 프 & 3 New Tools for handling operations inside reactor building + Spares & $\$ 200,000.00$ & 12 mons & Mon $10 / 2 / 17$ & Fri $8 / 31 / 18$ \\
\hline 164 & 目 & Analysis of Other Tools & $\$ 500,000.00$ & 12 mons & Mon $10 / 2 / 17$ & Fri $8 / 31 / 18$ \\
\hline 165 & & Removal of Spent Fuel from cask & $\$ 350,000.00$ & 12 mons & Mon 10/2/17 & Fri 8/31/18 \\
\hline 166 & 目 & Drop Analysis & $\$ 300,000.00$ & 12 mons & Mon $10 / 2 / 17$ & Fri $8 / 31 / 18$ \\
\hline 167 & 四 & Hoist issues & $\$ 50,000,00$ & 1 mon & Mon $10 / 2 / 17$ & Fri $10 / 27 / 17$ \\
\hline 168 & & Spent Fuel Storage & $\$ 2,150,000.00$ & 12 mons & Mon 10/2/17 & Fri 8/31/18 \\
\hline 169 & 四 & Structural Analysis: Shielding, Thermal, Criticality & $\$ 2,000,000,00$ & 12 mons & Mon 10/2/17 & Fri $8 / 31 / 18$ \\
\hline 170 & 프 & Environmental Assessment & $\mathbf{S 1 5 0 , 0 0 0 . 0 0}$ & 6 mons & Mon $10 / 2 / 17$ & Fri $3 / 16 / 18$ \\
\hline 171 & & Documentation & $\$ 1,500,000.00$ & 24 mons & Mon 10/2/17 & Fri 8/2/19 \\
\hline 172 & 프 & Upgraded approval & $\$ 1,500,000,00$ & 24 mons & Mon $10 / 2 / 17$ & Fri $8 / 2 / 19$ \\
\hline 173 & 园 & Sabotage Assessment & $\$ 300,000.00$ & 6 mons & Mon $10 / 2 / 17$ & Fri $3 / 16 / 18$ \\
\hline 174 & 四 & Transfer of responsibilty for fuel to SRS & $\$ 0.00$ & 1 mon & Fri $4 / 3 / 20$ & Thu $4 / 30 / 20$ \\
\hline
\end{tabular}




\section{SUMMARY AND CONCLUSIONS}

Based on this preliminary plan, the total cost to ORNL expected to be funded by NNSA for conversion of the HFIR from HEU to LEU fuel through operation of the reactor with the first commercially fabricated core is $\$ 76$ million. A summary of costs by year based on the information presented in the previous section is shown in Table 3.1 and graphically presented in Fig. 3.1. A summary of costs by topic is provided in Table 3.2.

The purpose of this study was to respond to a request from the Department of Energy to prepare a schedule for the conversion of HFIR from HEU to LEU as input to an integrated multi-reactor conversion program plan. This HFIR plan is subject to revision based on feedback from the conversion program manager and other emerging developments. This HFIR plan was developed under the constraint that the conversion be completed by the end of fiscal year 2016. Upon completion of this task, one item has been identified as a potentially significant reduction to project cost - coordination with other U.S. reactor conversions to receive in-reactor measurement data and post-irradiation examination data thereby minimizing the number of tests needed to be performed at HFIR.

All policy decisions have significant technical and financial ramifications. Their consideration involves both the Department of Energy Office of Science and the National Nuclear Security Administration. Furthermore, two national laboratories (Oak Ridge and Los Alamos), the Y-12 National Security Complex, and any potential LEU fuel fabricators would be impacted by any changes to these policy decisions. Clearly such discussion is beyond the scope of the current study.

Table 3.1. HFIR LEU conversion cost by year

\begin{tabular}{|c|c|c|}
\hline \multirow{2}{*}{ Fiscal Year } & \multicolumn{2}{|c|}{$\begin{array}{c}\text { Cost } \\
\text { (thousands of dollars) }\end{array}$} \\
\cline { 2 - 3 } & Annual & Cumulative \\
\hline 2010 & 2,315 & 2,315 \\
\hline 2011 & 14,689 & 17,004 \\
\hline 2012 & 6,883 & 23,886 \\
\hline 2013 & 7,284 & 31,170 \\
\hline 2014 & 3,613 & 34,784 \\
\hline 2015 & 10,233 & 45,017 \\
\hline 2016 & 21,392 & 66,409 \\
\hline 2017 & 616 & 67,025 \\
\hline 2018 & 4,313 & 71,338 \\
\hline 2019 & 2,306 & 73,644 \\
\hline 2020 & 1,975 & 75,619 \\
\hline 2021 & 446 & 76,065 \\
\hline Grand Total & \multicolumn{2}{|c|}{$\$ 76,065$} \\
\hline
\end{tabular}


Table 3.2 HFIR LEU conversion cost by topic

\begin{tabular}{|c|c|c|c|c|c|c|}
\hline ID & (1) & Task Name & Cost & Duration & Start & Finish \\
\hline 1 & & Conversion of HFIR from HEU to LEU (Pre-decisional) & $\$ 76,065,000.00$ & 148.85 mons & Thu $10 / 1 / 09$ & Fri $2 / 26 / 21$ \\
\hline \multicolumn{7}{|l|}{2} \\
\hline 3 & & Input required from organizations outside UT-Battelle/ORNL & $\$ 8,460,000.00$ & 89.2 mons & Thu 10/1/09 & Tue $8 / 2 / 16$ \\
\hline \multicolumn{7}{|l|}{54} \\
\hline 55 & 8 & Quality assurance approval/audit by HFIR staff for operations outside HFIR site & $\$ 600,000.00$ & 100.2 mons & Thu 10/1/09 & Tue 6/6/17 \\
\hline \multicolumn{7}{|l|}{65} \\
\hline 66 & & LEU fuel design studies & $\$ 5,515,000.00$ & 48.35 mons & Thu $10 / 1 / 09$ & Fri $6 / 14 / 13$ \\
\hline \multicolumn{7}{|l|}{87} \\
\hline 88 & 8 & Fresh Fuel Shipping Cask (from fuel fabricator to HFIR) & $\$ 10,000,000.00$ & 86 mons & Fri $10 / 1 / 10$ & Thu $5 / 4 / 17$ \\
\hline \multicolumn{7}{|l|}{104} \\
\hline 105 & 8 & HFIR Reactor Building (7900) & $\$ 45,400,000.00$ & 135.8 mons & Fri $10 / 1 / 10$ & Fri $2 / 26 / 21$ \\
\hline \multicolumn{7}{|l|}{155} \\
\hline 156 & 8 & Spent Fuel Shipping Cask & $\$ 1,090,000.00$ & 124 mons & Fri 10/1/10 & Thu $4 / 2 / 20$ \\
\hline \multicolumn{7}{|l|}{160} \\
\hline 161 & 8 & HFIR to Savannah River Lab - Receipt of spent fuel & $\$ 5,000,000.00$ & 137.2 mons & Mon 10/26/09 & Thu $4 / 30 / 20$ \\
\hline
\end{tabular}

Fig. 3.1 Conversion project expense

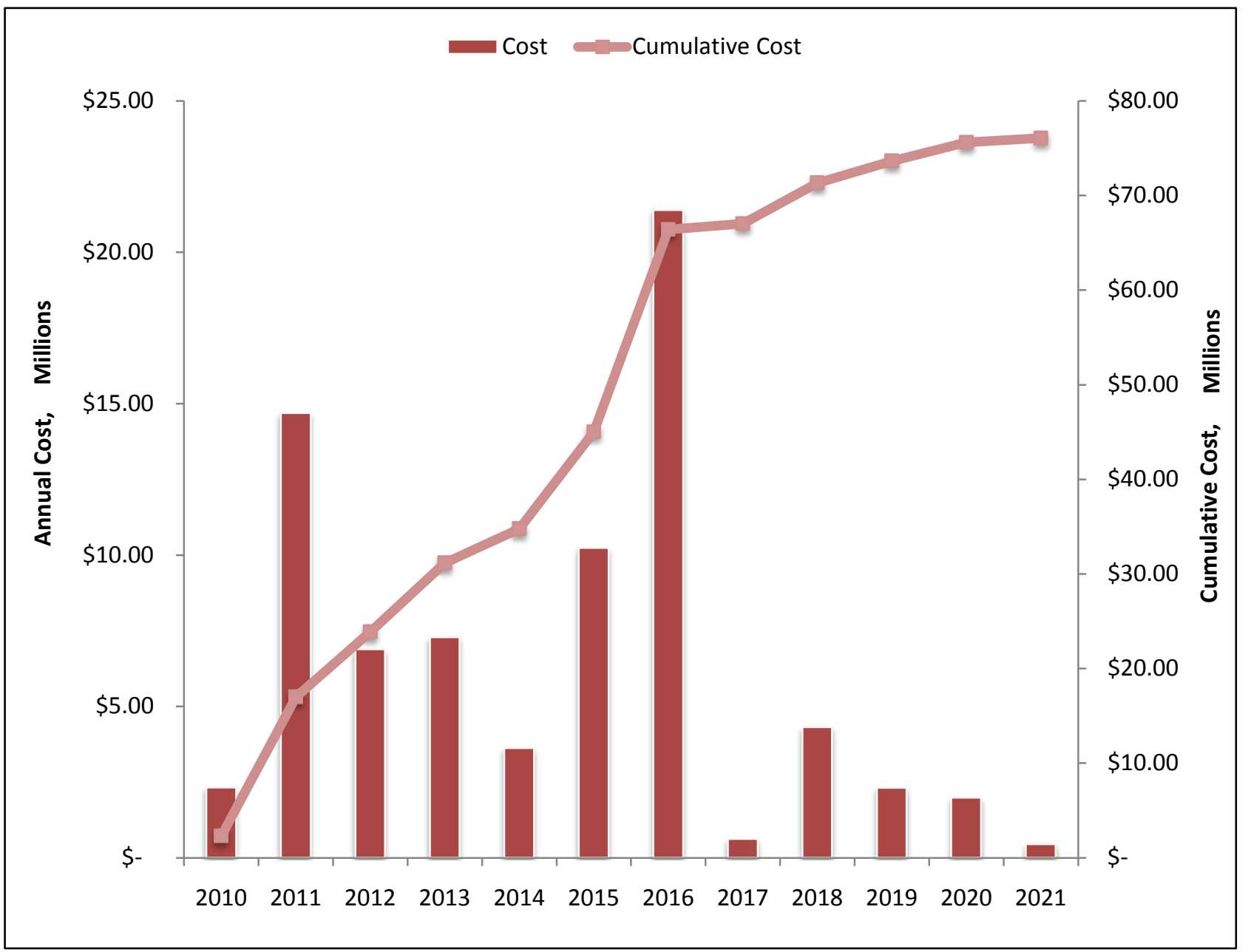




\section{REFERENCES}

1. R. D. Cheverton and T. M. Sims, HFIR Core Nuclear Design, ORNL-4621, Oak Ridge National Laboratory (1971).

2. R.T. Primm III, R.J Ellis, J.C. Gehin, D.L. Moses, J.L. Binder, and N. Xoubi, Assumptions and criteria for performing a feasibility study of the conversion of the High Flux Isotope Reactor core to use low-enriched uranium fuel, ORNL/TM-2005/269, Oak Ridge National Laboratory (2006).

3. R. T. Primm III, R. J. Ellis, J. C. Gehin, K. T. Clarno, K. A. Williams, and D. L. Moses, Design Study for a Low-Enriched Uranium Core for the High Flux Isotope Reactor, Annual Report for FY 2006, ORNL/TM-2006/136, November 2006.

4. R. T. Primm III, R. J. Ellis, J. C. Gehin, G. Ilas, J. H. Miller, and J. D. Sease, Design Study for a Low-Enriched Uranium Core for the High Flux Isotope Reactor, Annual Report for FY 2007, ORNL/TM-2007/45, November 2007.

5. R. T. Primm III, D. Chandler, G. Ilas, B. C. Jolly, J. H. Miller, and J. D. Sease, Design Study for a Low-Enriched Uranium Core for the High Flux Isotope Reactor, Annual Report for FY 2008, ORNL/TM-2009/87, March 2009.

6. United States Department of Energy, Integration of Safety into the Design Process, DOE Standard, DOE-STD-1189-2008, March 2008.

7. http://www.em.doe.gov/Pages/spentfuel.aspx?compid=1 , December 2009.

8. J. D. Sease, R. T. Primm III, and J. H. Miller, Conceptual Process for the Manufacture of Lowenriched Uranium/Molybdenum Fuel for the High Flux Isotope Reactor, ORNL/TM-2007/39, September 2007. 


\section{APPENDIX A RISKS AND OPPORTUNITIES}

\begin{tabular}{|c|c|c|}
\hline RISK GROUP & MAGNITUDE & PROBABILITY \\
\hline $\begin{array}{l}\text { 1. Incorrect or inadequate safety and performance analyses e.g., } \\
\text { - accident analysis fails to demonstrate adequate safety margin at } \\
100 \text { MW } \\
\text { - accident analysis identifies new issues } \\
\text { - impacts of increased decay heat load relative to current cycle } \\
\text { require major plant changes } \\
\text { - modified reactor control parameters due to LEU/HEU neutronic } \\
\text { differences } \\
\text { - seismic/structural analyses fail to demonstrate adequate margin } \\
\text { for reactor vessel } \\
\text { - LEU changes lead to unacceptable results in HFIR PRA }\end{array}$ & High & High \\
\hline $\begin{array}{l}\text { 2. Unacceptable increase in dose consequences due to changes in } \\
\text { LEU spent fuel fission product inventory }\end{array}$ & Medium & Low \\
\hline $\begin{array}{l}\text { 3. Analyses of LEU spent fuel operations require major plant } \\
\text { changes e.g., } \\
\text { - revised criticality analyses for storage and transportation } \\
\text { - revised structural analyses for storage and transportation }\end{array}$ & Medium & Low \\
\hline $\begin{array}{l}\text { 4. Difficulties in obtaining regulatory approvals (by others) e.g., } \\
\text { - revised safety analyses } \\
\text { - revised environmental impact documentation } \\
\text { - revised transportation safety documentation } \\
\text { - conduct and resolve issues from operational readiness reviews } \\
\text { (not currently in HFIR project plan) } \\
\text { - acceptance of spent fuel at SRS }\end{array}$ & High & High \\
\hline $\begin{array}{l}\text { 5. Inadequate or unacceptable results from LEU fuel development } \\
\text { and manufacturing efforts by others e.g., } \\
\text { - acceptability of flow, irradiation, and post-irradiation testing } \\
\text { - on-time availability of test results } \\
\text { - ability to fabricate HFIR-spec fuel } \\
\text { - quality of fuel from commercial vendor } \\
\text { - on-time delivery of fuel from commercial vendor } \\
\text { - cost of fuel from commercial vendor over remaining life of HFIR }\end{array}$ & High & Very high \\
\hline $\begin{array}{l}\text { 6. Insufficient HFIR resources to support both ongoing operations } \\
\text { and LEU conversion activities with projected staffing and budget } \\
\text { due to overall impact of additional LEU work scope and increased } \\
\text { cost of HEU fuel during transition }\end{array}$ & High & High \\
\hline $\begin{array}{l}\text { 7. Significant contamination of HFIR systems and structures from } \\
\text { LEU fuel failure impacts continued operations }\end{array}$ & High & Low \\
\hline
\end{tabular}

\begin{tabular}{|l|c|c|}
\hline \multicolumn{1}{|c|}{ OPPORTUNITY GROUP } & MAGNITUDE & PROBABILITY \\
\hline $\begin{array}{l}\text { 1. New safety analysis tools improve current safety strategies e.g., } \\
\text { reactor confinement }\end{array}$ & Medium & Low \\
\hline 2. New fuel handling tooling not needed & Low & Low \\
\hline
\end{tabular}


ORNL/TM-2009/311

\section{INTERNAL DISTRIBUTION}

1. K. J. Beierschmitt (beierschmitt@ornl.gov)

2. S. E. Burnette (burnettese@ornl.gov)

3. D. C. Christensen (christensend@ornl.gov)

4. R. A. Crone (cronera@ornl.gov)

5. R. J. Ellis (ellisrj@ornl.gov)

6. G. Ilas (ilasg@ornl.gov)

7. J. H. Miller (millerjh2@ornl.gov)
8-10. R. T. Primm III (primmrtiii@ornl.gov)

11. R. R. Rawl (rawlrr@ornl.gov)

12. J. E. Rushton (rushtonje@ornl.gov)

13. L. J. Satkowiak (satkowiaklj@ornl.gov)

14. J. D. Sease (seasejd@ornl.gov)

15. K. A. Smith (smithka@ornl.gov)

16. ORNL Laboratory Records (hamrindr@ornl.gov)

\section{EXTERNAL DISTRIBUTION}

17. J. Matos, Argonne National Laboratory, 9700 S. Cass Avenue, Argonne, IL 60439 (jim.matos@anl.gov)

18. D. M. Hewitt, Idaho National Laboratory, P.O. Box 1625, Idaho Falls, ID 83415-3750 (Dana.Hewitt@inl.gov)

19. J. Roglans, Argonne National Laboratory, 9700 S. Cass Avenue, Argonne, IL 60439 (roglans@anl.gov)

20. P. Staples, NA-212, U.S. Department of Energy, 1000 Independence Avenue SW, Washington, DC 20585 (Parrish.Staples@nnsa.doe.gov)

21. John Stevens, Argonne National Laboratory, 9700 S. Cass Avenue, Argonne, IL 60439 (johnstevens@anl.gov)

22. Daniel M. Wachs, MFC 791 B-147, Idaho National Laboratory, P.O. Box 6188, Idaho Falls, ID 83415 (Daniel.Wachs@inl.gov)

23. Tracey Guida, University of Pittsburgh, Pittsburgh, PA, 15260 (tlg29+@pitt.edu)

24. Kathy Garcia, NA-212, U.S. Department of Energy, 1000 Independence Avenue SW, Washington, DC 20585 (Kathy.Garcia@nnsa.doe.gov)

25. Morris Hassler, Y-12 National Security Complex, (hasslerme@y12.doe.gov)

26. Eric C Woolstenhulme, P.O. Box 1625, Idaho Falls, ID 83415-3750 (Eric.Woolstenhulme@inl.gov)

27. Roger Klaffky, Office of Basic Energy Sciences, U.S. Department of Energy, 1000 Independence Avenue SW, Washington, DC 20585 (roger.klaffky@science.doe.gov).

28. Pedro Mantano, Office of Basic Energy Sciences, U.S. Department of Energy, 1000 Independence Avenue SW, Washington, DC 20585 (pedro.montano@science.doe.gov).

30. Carol Sohn, of Basic Energy Sciences, U.S. Department of Energy (carol.sohn@pnso.science.doe.gov).

31. Johnny O. Moore, U. S. Department of Energy, (moorejo@ornl.gov) 